\title{
The effect of sodium chloride salinity on coated and uncoated alfalfa seeds germination
}

\section{Sodyum klorür tuzluluğunun kaplamalı ve kaplamasız yonca tohumlarının çimlenmesi üzerine etkisi}

\author{
Sinan SÜHERi ${ }^{1 *}$ iD, ilknur Kutlar YAYLALI ${ }^{1}$ (D) Duran YAVUZ ${ }^{1}$ iD Nurcan YAVUZ $^{1}$ iD \\ ${ }^{1}$ Selcuk University Agricultural Faculty Farm Structure and Irrigation Department
}

To cite this article:

Süheri, S., Yaylalı, I..K., Yavuz, D. \& Yavuz, N. (2019). The effect of sodium chloride salinity on coated and uncoated alfalfa seeds germination. Harran Tarım ve Gıda Bilimleri Dergisi, 23(1): 31-38. DOI: 10.29050/harranziraat.406323

Address for Correspondence: Sinan SÜHERI

e-mail:

ssuheri@selcuk.edu.tr

Received Date:

15.03.2018

Accepted Date:

18.01.2019

(c) Copyright 2018 by Harran University Faculty of Agriculture. Available on-line at www.dergipark.gov.tr/harranziraat

\section{ABSTRACT}

In this study, a pod experiment was conducted to evaluate the effect of sodium chloride salinity on germination of coated and uncoated seeds of alfalfa seeds under controlled greenhouse conditions at Konya in May 2013. The experimental design was a split-split plot with salinity treatments as main plots, coated and uncoated seeds subplots. Pots were

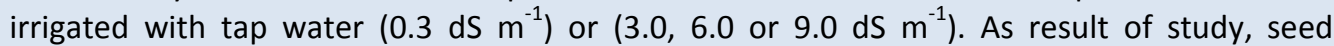
germination was significantly affected by irrigation water salinity at the initial stage of germination. For coated and uncoated seed, the final seed germination exceeded $79.00 \%$ except at the salt concentrations higher than $3.0 \mathrm{dSm}^{-1}$ where germination percentage statically decreased down. The highest germination rate index (GRI, 14.29\%), germination index (GI, 998.75), and coefficient of velocity of germination (CVG, 16.97) values were obtained from the coated seeds irrigated with the tap water while the lowest GRI (1.79\%), GI (138.75), and CVG (12.57) values were obtained from the uncoated seeds irrigated with salt concentration of electrical conductivity (EC) of $12.0 \mathrm{dS} \mathrm{m}^{-1}$. Earlier germinations were recorded for coated seeds as indicated by lower value of mean germination time (MGT) and time of $50 \%$ germination $\left(T_{50}\right)$.

\section{Key Words: Medicago sativa, Emergence, Chlorinity, Lime}

Öz

Bu çalışma, Mayıs 2013 tarihinde Konya'da kontrollü sera şartlarında sodyum klorür tuzluluğunun kaplanmış ve kaplanmamış yonca tohumları çimlenmesi üzerine etkisinin araştırılması amacıyla yürütülmüştür. Saksı denemesi olarak kurulan deneme, tuzluluk ana muamele, kaplanmış ve kaplanmamış yonca tohumları alt muamele olarak bölünmüş parsel deneme planına göre tasarlanmıştır. Saksılar musluk suyu $\left(0.3 \mathrm{dS} \mathrm{m}^{-1}\right)$ veya elektriksel

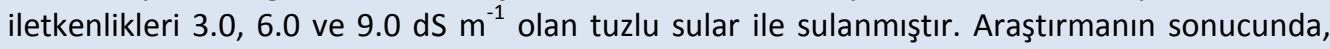
tuzluluğun çimlenmenin başlangıç aşamasında tohumların çimlenmesini önemli derecede etkilediği, kaplanmış ve kaplanmamış tohumlarda, toplam çimlenme yüzdesinin, $3.0 \mathrm{dS} \mathrm{m}^{-1}$ değerinden daha yüksek tuzluluk seviyeleri hariç olmak üzere \%79'un üzerinde olduğu, 3.0 dS $\mathrm{m}^{-1}$ değerinden daha yüksek sulama suyu tuzluluk değerlerinde çimlenmenin istatistiki olarak farklı olduğu, en yüksek çimlenme oran indeksi (\%14.29), çimlenme indeksi (998.75), ve çimlenme hızı katsayı (16.97) değerlerinin musluk suyu ile sulanan kaplanmış tohumlardan, en düşük çimlenme oran indeksi (\%1.79), çimlenme indeksi (138.75) ve çimlenme hızı katsayısı (12.57) değerlerinin ise elektriksel iletkenliği $12.0 \mathrm{dS} \mathrm{m}^{-1}$ olan suyla sulanan kaplanmamış tohumlardan elde edildiği tespit edilmiştir. Erken çimlenme değerlerinin düşük ortalama çimlenme zamanı (MGT) ve \%50 çimlenme zamanı $\left(T_{50}\right)$ değerlerinin elde edildiği kaplanmış tohumlarda görüldüğü bulunmuştur.

Anahtar Kelimeler: Medicago sativa, Çıkış, Tuzluluk, Kireç 


\section{Introduction}

Alfalfa (Medicago sativa L.) is high quality perennial legume forages for livestock all over the world. It is defined as queen of the forages because of its high nutritional quality. Alfalfa evolved in an area that has a pronounced continental climate with cold winters and hot, dry summers. A late spring and short summer characterize these regions (Hanson and Kehr, 1972). In Turkey, alfalfa cultivated land has increased from 539.000 ha (2007) to 659.000 ha (2017) over period of ten years in Turkey. It is cultivated on over 659.000 ha in solid stand, which is about $3 \%$ of total agricultural land and $12 \%$ of total irrigated agricultural land in Turkey (TUiK, 2018). Although it is cultivated for many years, there is lack of alfalfa varieties improved in Turkey. So alfalfa seeds are being imported in large quantities to Turkey.

Increasing world population requires greater food production in future. One way to meet this need is to bring marginally productive and presently non-arable land, much of which affected by salinity, under crop production (Allen et al., 1985). The large areas of saline soils and brackish water resources are under utilized worldwide for crop production. The Konya basin where the experiment conducted has a semi arid climate. In this areas where rainfall is insufficient to leach salts from the root zone and evaporation tends to exceed rainfall, salinity remains a major problem facing agriculture.

Although some crops are moderately tolerant of saline conditions many crops are adversely affected by even levels of salt (Greenway and Munns, 1980). In saline environment of plants to salinity during germination and early seedling stages is crucial for the establishment of species. Seedlings are the most vulnerable stage in the life cycle of plants and germination determines when and where seedling growth begins (Gutterman, 2012).

Although alfalfa is a crop that is considered moderately sensitive to salinity (Maas and Hoffman, 1977), (Lehman et al., 1979), it is regarded as susceptible to salts at seed germination (Assadian and Miyamoto, 1987). Coated seeds are accepted widely as a standard product for many crops. Alfalfa and tobacco are two agronomic crops that are coated. (Kaufman, 1991). Seed coating is the practice of covering seeds with external materials to improve handling, protection and to a lesser extent, germination enhancement and plant establishment (Pedrini et al., 2017).

The volume of alfalfa seeds being sold as coated seeds has been increasing for several years in Turkey. The coating normally contains Rhizobia inoculant, fungicides and lime based materials. Therefore, it is generally considered that coating of alfalfa seeds can increase plant establishment.

The objective of this study was to evaluate the effects of coating on germination of alfalfa seeds when the different salinity level water used for irrigation.

\section{Materials and Methods}

The experiment was carried out in May 2013 in a greenhouse at Selcuk University Agriculture Faculty in Konya, Turkey with two alfalfa (Medicago sativa L.) seeds as coated and uncoated. Alfalfa seed cultivar was Magnum $\mathrm{V}$ which is registered variety in Turkish Seed Catalogue. The greenhouse where the experiment conducted was glass covered, $250 \mathrm{~m}^{2}$ and computer controlled. During experiment, maximum temperature, minimum temperature and relative humidity were maintained as $26 \pm 2$ ${ }^{\circ} \mathrm{C}, 16 \pm 2{ }^{\circ} \mathrm{C}$ and $65 \% \pm 5$ respectively. The Konya has arid to semi arid climate. Annual rainfall is about $322 \mathrm{~mm}$ and mean temperature is $11.6^{\circ} \mathrm{C}$ with minimum mean temperature of $-4.6{ }^{\circ} \mathrm{C}$ in January and maximum mean temperature of 30.1 in July. The sample seeds was treated with Apron XL LS a Fungicide, NitrogenGold - an inoculant and coated with a lime based build up (50\%) were purchased from Biotek Seeds Company (Konya, Turkey). The mean seed dry weight per 1000 seeds for coated and uncoated seeds were 3.1 
gram and 6.0 gram respectively. Seed moisture ranged between 6 and $7 \%$. When the experiment was conducted, the seeds were less than 12 months old and had been previously stored in bags under laboratory conditions. The seeds were hand-sorted from the coated seed lot and noncoated seeds lots. Treatment was developed by washing the coated seeds with water for $5 \mathrm{~min}$, which effectively removed all the seed coating from the seeds then counted into 100 seed lots. The coated and non-coated seeds were planted immediately after washing into the soils on 8 May 2016. Loamy sand soil taken from a field which previously carried a wheat crop was used for the experiment mainly because of its low crusting potential. The soil with $\mathrm{pH}$ of 7.75 , electrical conductivity of saturation extract (ECe) of 1.40 $\mathrm{dSm}^{-1}$, sodium adsorption ratio (SAR) of 4.25 and field capacity of $21.2 \%$ and permanent wilting percentage of $12.2 \%$ by weight was air-dried and sieved through a $2 \mathrm{~mm}$ mesh and filled to the plastic pods with a mean diameter of $23 \mathrm{~cm}$ an height of $21 \mathrm{~cm}$. The bulk density and available water holding capacity of the soil were $1.43 \mathrm{gr}$ $\mathrm{cm}^{-3}$ and $1.29 \mathrm{~mm} / \mathrm{cm}$ respectively. 100 alfalfa seeds were sown in each pot to a depth $1.5 \mathrm{~cm}$. The plant root zone depth was considered same as height of plastic pods.

The experimental design was a split-split plot with salinity treatments as main plots, coated and uncoated seeds subplots. All treatments were replicated four times.

Saline solutions were prepared with $\mathrm{NaCl}$. The electrical conductivity (EC) of the solutions were determined with a conductivity meter (model PCM 3, Jenway, Felstead,UK). The electrical conductivity of the treatments were tap water $\left(0.3 \mathrm{dSm}^{-1}\right)$ or $\left(3.0,6.0,9.0\right.$ or $\left.12.0 \mathrm{dSm}^{-1}\right)$.

Irrigation water was applied to maintain field capacity of soil depending upon irrigation interval ranging 3 days. The amount of irrigation varied between 0,5 to 0,9 liter per pot per irrigation depending upon irrigation interval. The irrigation water did not have any direct contact with plant leaves during irrigation applications. Crop germination was recorded daily till all the seeds were germinated and emerged from the soil surface. A seedling with the hypocotyls or cotyledon showing on the soil surface was regarded as having emerged. To measure the effect of treatments on seed and seedling performance, coefficient of velocity of germination (CVG), germination index (GI), germination rate index (GRI), mean germination time (MGT), time of $50 \%$ germination $\left(T_{50}\right)$, final germination percentage (FGP), first day o germination (FDG), Last day of germination (LDG), Time spread of germination (TSG), were calculated by following formulas. $C V G=100 \times \sum N i / \sum N i T i$, where $\mathrm{Ni}$ is the number of germinated seeds for each day, Ti is number of days from seedling (Jones and Sanders, 1987), $\quad G I=17 \times N_{1}+16 \times N_{2}+\ldots \ldots . .+1 \times N_{17}$, where $N_{1}, N_{2} \ldots . . . N_{17}$ of germinated seeds on the first, second and subsequent days until the $17^{\text {th }}$ day, $17,16, \ldots$ and 1 are weights given to the number of germinated seeds on first, second and subsequent days, respectively (Benech Arnold et al., 1991), where, $G_{1}$ is the germination percentage at first day, $G_{2}$ is the germination percentage at second day and so forth (Esechie, 1994), $M G T=\frac{\sum N i T_{i}}{\sum N_{i}}$, where $\mathrm{N}_{\mathrm{i}}$ is the number of germinated seeds for each day, $T_{i}$ is number of days counted from the beginning of germination (Orchard, 1977), $F G P=\frac{N_{g}}{N_{t}} \times 100$, where, $\mathrm{N}_{\mathrm{g}}$ is total number of germinated seeds, $N_{t}$ is total number of evaluated seeds. The time of $50 \%$ germination $\left(T_{50}\right)$ was calculated according to the following formula of Coolbear et al. (1984) modified by Farooq et al., (2006). $T_{50}=t i+\frac{\left[(N / 2)-n_{i}\right]\left(t_{i}-t_{j}\right)}{n_{i}-n_{j}}$, where $\mathrm{N}$ is the final number of germination and $n_{i}, n_{j}$ cumulative number of seeds germinated by adjacent count at times $t_{i}$ and $t_{j}$ when $n_{i}<N / 2<n_{j}$

Data of the germination parameters were statistically analyzed one-way analysis of variance (ANOVA) using SPSS version 9.0 (SPSS, 1999). The 
analyses of variance were conducted separately within each seed treatments, considering water salinity and seed treatment as fixed factors. When " $F$ " ratios were significant, means were separated by the Duncan's test ( $p \leq 0.005)$.

\section{Results and Discussion}

The first sign of germination was observed after 5 days except treatments irrigated with water EC of $12.0 \mathrm{dSm}^{-1}$ in both coated and uncoated seeds. For the treatments irrigated with the water EC of $12.0 \mathrm{dSm}^{-1}$ first germination was observed on $6^{\text {th }}$ day with $\% 1$ and $\% 2.5$ germination rate for uncoated and coated seeds respectively.

The final seed germination ranged between $13.50 \%$ and $80,50 \%$ for uncoated seeds and $20,25 \%$ and $82.50 \%$ for coated seeds receiving waters of different salinities. The germination of uncoated seeds decreased down to $79.25 \%$ with water EC of $3.0 \mathrm{dSm}^{-1}, 55.75 \%$ with water EC 6.0 $\mathrm{dSm}^{-1}, 43.50 \%$ with water EC of $9.0 \mathrm{dSm}^{-1}, 13.50 \%$ with water EC of $12.0 \mathrm{dSm}^{-1}$ while the germination of coated seeds decreased down to $80,75 \%$ with water EC of $3.0 \mathrm{dSm}^{-1}, 63.50 \%$ with water EC $6.0 \mathrm{dSm}^{-1}, 45.25 \%$ with water EC of 9.0 $\mathrm{dSm}^{-1}, 20,25 \%$ with water EC of $12.0 \mathrm{dSm}^{-1}$. The difference in final germination was not statistically significant between EC of $0,3 \mathrm{dSm}^{-1}$ and EC of $3.0 \mathrm{dSm}^{-1}$ treatments. The final germination percentage showed decreasing trend with increase in water salinity. For coated and uncoated seed, the final seed germination exceeded $79.00 \%$ except at the salt concentrations higher than $3.0 \mathrm{dSm}^{-1}$ where germination percentage statically decreased down (Table 1, Figure 1). Earlier studies stated that alfalfa is susceptible to salinity at stage of germination (Assadian and Miyamoto, 1987; James, 1988; Ungar, 1967; Wang et al., 2009). The results showed that fair emergences can be obtained when the seeds are irrigated with water has higher than EC of $3.0 \mathrm{dSm}^{-1}$. For salt concentration lower than $3.0 \mathrm{dSm}^{-1}$, when the salt concentration increase ten times more, the final germination percentage for uncoated and coated seeds hasn't decreased more than $2 \%$. But for the salt concentrations higher than $3.0 \mathrm{dSm}^{-1}$, the final germination percentage decreased dramatically (Fig. 1). Many researches such as $\mathrm{Li}$ et al. (2010), Wang et al. (2009), Johnson et al. (1992), and Assadian and Miyamoto (1987) has stated that salt concentration has negative effects on germination of alfalfa seeds. The results obtained from this study are in compliance with previous studies.

Table 1. Effect of irrigation water salinity and seed treatment (UC=Uncoated; C=Coated) Upon FGP(\%), GRI, GI And CVG . Çizelge 1. Sulama suyu tuzluluğu ve tohum uygulamalarının (K: Kaplanmış; NK:Kaplanmamış) ÇY (\%), ÇOI, Çı Ve ÇHK Etkisi

\begin{tabular}{|c|c|c|c|c|c|c|c|c|c|c|c|c|}
\hline \multirow{2}{*}{$\begin{array}{c}\text { Salinity levels } \\
\text { Tuzluluk seviyesi }\left(\mathrm{dSm}^{-1}\right)\end{array}$} & \multicolumn{3}{|c|}{$\begin{array}{l}\text { FGP (\%) } \\
\text { ÇY (\%) }\end{array}$} & \multicolumn{3}{|c|}{$\begin{array}{l}\text { GRI } \\
\text { ÇOI }\end{array}$} & \multicolumn{3}{|c|}{$\begin{array}{l}\mathrm{Gl} \\
\mathrm{ÇI}\end{array}$} & \multicolumn{3}{|c|}{$\begin{array}{l}\text { CVG } \\
\text { ÇHK }\end{array}$} \\
\hline & $\begin{array}{c}\text { UC } \\
K\end{array}$ & $\begin{array}{c}\mathrm{C} \\
\mathrm{NK}\end{array}$ & $\begin{array}{c}\text { Mean } \\
\text { Ort. }\end{array}$ & $\begin{array}{c}\text { UC } \\
K\end{array}$ & $\begin{array}{c}\mathrm{C} \\
\mathrm{NK}\end{array}$ & \begin{tabular}{|l} 
Mean \\
Ort.
\end{tabular} & $\begin{array}{l}\text { UC } \\
K\end{array}$ & $\begin{array}{c}\mathrm{C} \\
\mathrm{NK}\end{array}$ & $\begin{array}{l}\text { Mean } \\
\text { Ort. }\end{array}$ & $\begin{array}{c}\text { UC } \\
\mathrm{K}\end{array}$ & $\begin{array}{c}\mathrm{C} \\
\mathrm{NK}\end{array}$ & $\begin{array}{l}\text { Mean } \\
\text { Ort. }\end{array}$ \\
\hline 0,3 & 80,50 & 82.50 & $81.50 a$ & 13.20 & 14.29 & $13.74 a$ & 922.75 & 998.75 & $960,75 a$ & 15.32 & 16.97 & $16.15 a$ \\
\hline 3.0 & 79.25 & 80,75 & $80,00 a$ & 12.54 & 13.53 & $13.04 a$ & 878.25 & 961.50 & 919.88a & 14.93 & 16.41 & 15.67ab \\
\hline 6.0 & 55.75 & 63.50 & $59.63 b$ & 8.28 & 9.89 & $9.11 b$ & 614.50 & 716.00 & $667,38 b$ & 14.37 & 14.81 & $14.69 \mathrm{bc}$ \\
\hline 9.0 & 43.50 & 45.25 & $44.38 \mathrm{c}$ & 6.01 & 6.81 & $6.41 c$ & 459.00 & 506.00 & $482.50 \mathrm{c}$ & 13.39 & 14.49 & $13.94 \mathrm{c}$ \\
\hline 12.0 & 13.50 & 20,25 & $16.63 d$ & 1.79 & 2.58 & $2.19 d$ & 138.75 & 199.00 & $168.88 \mathrm{~d}$ & 12.57 & 12.94 & 12.75 \\
\hline Mean & \begin{tabular}{|l|}
$54.50 a$ \\
\end{tabular} & $58.45 a$ & & $8.36 b$ & $9.42 a$ & & $602.65 a$ & $676.25 a$ & & $14.12 \mathrm{a}$ & $15.05 a$ & \\
\hline
\end{tabular}

FGP: First Germination Percentage GRI: Germination Rate Index, GI: Germination Index, CVG: Coefficient of Velocity of Germination

ÇY : Final Çimlenme Yüzdesi ÇOI: Çimlenme Oranı İndeksi, Çı :Çimlenme İndeksi ÇHK :Çimlenme Hızı Katsayısı

The seed germination exceeded $80 \%$ within 7 days for coated seeds and 15 days for uncoated seeds when the seeds were irrigated with tap water. The seed germination for coated and uncoated seeds didn't exceed $80 \%$ on the other salt concentrations except for coated seed irrigated with salt concentration of EC of $3.0 \mathrm{dSm}^{-}$ ${ }^{1}$. The seed germination exceeded $80 \%$ within 9 days on this treatment. 


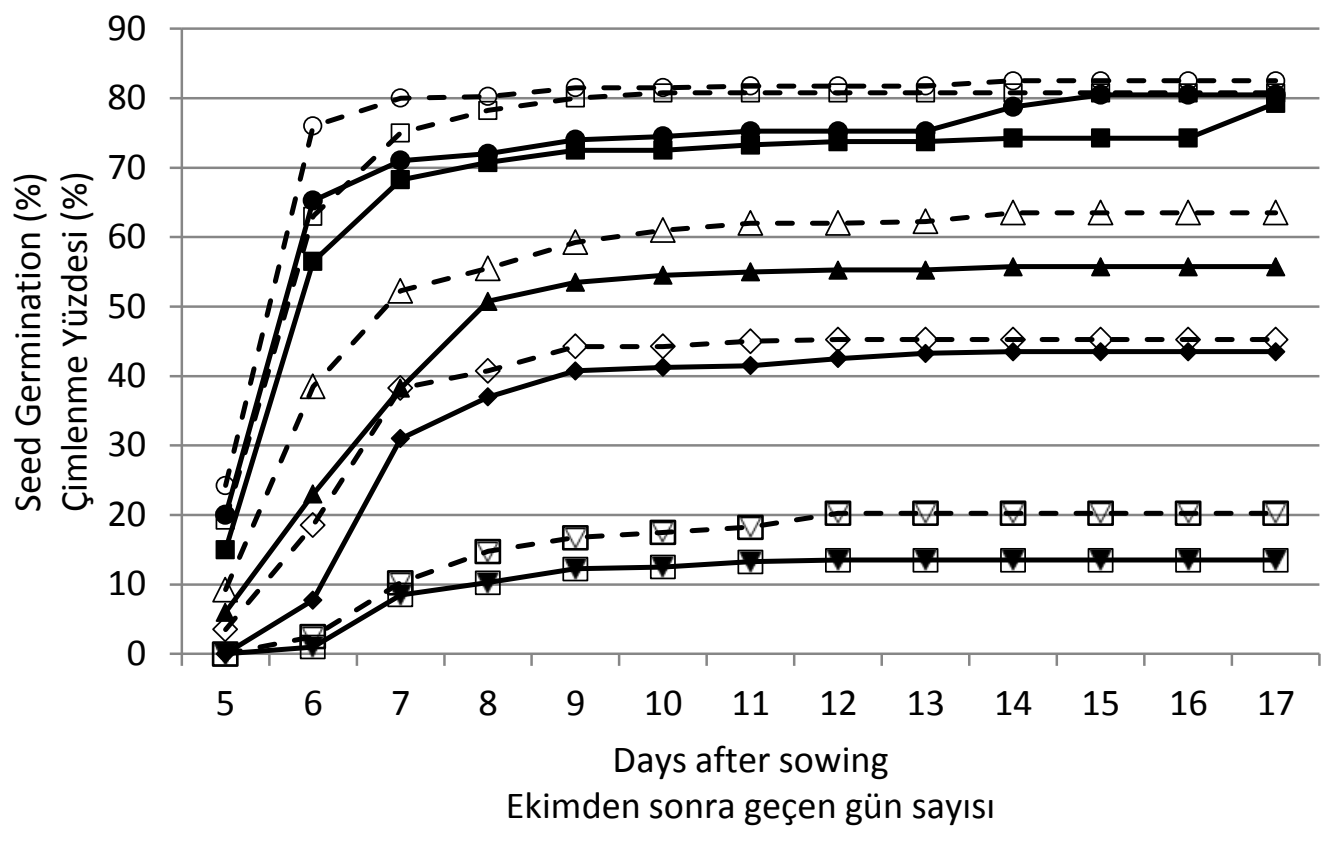

Figure 1. Cumulative seed germination of uncoated (UC, closed symbols) and coated (C, open symbols) alfalfa seeds. Symbols represent the observed percentages with time at each water salinity.

Şekil 1. Kaplamalı (C, açık sembol) ve kaplamasız (UC, kapalı sembol) yonca tohumlarının yığışımlı tohum çimlenmesi

The lower GRI, GI and CVG values were obtained with the increase in water salinity for both coated and uncoated seed. Earlier germinations were recorded for coated seeds as indicated by higher GRI, GI and CVG values (Table 1). The highest GRI (14.29\%), GI (998.75), and CVG (16.97) values were obtained from the coated seeds irrigated with the tap water while the lowest GRI (1.79\%), GI (138.75), and CVG (12.57) values were obtained from the uncoated seeds irrigated with the with salt concentration of EC of $12.0 \mathrm{dSm}^{-1}$. Results show that seed coating significantly affected GRI. GRI reflects the percentage of germination on each day of the germination period and basically gives an indication of the percentage of seeds germinating per day of the test run period (Al-Mudaris, 1998). According to results, It has concluded that the salt concentration in the irrigation water has decreased GRI significantly. Accordingly, the coating has increased the percentage of seed germinating per day.

Polynomial regression analysis was used to determine relationship between GRI, GI, CVG and different irrigation salinity level. It was found that strong negative relationship with $\mathrm{GRI}$ and $\mathrm{Gl}$ and irrigation water salinity with coefficient of determination $\left(R^{2}\right)$ ranged from 0.91 to $0.95 . R^{2}$ values obtained from coated seeds were higher than uncoated seeds, which means that the relationship between $\mathrm{GRI}, \mathrm{Gl}$ and irrigation water salinity is more strong for coated seeds.

Table 2. Effect of irrigation water salinity and seed treatment (UC=Uncoated; $C=$ Coated) upon MGT (Days) and T50.

Çizelge 2. Sulama suyu tuzluluğunun kaplanmış ve kaplanmamış tohumlarda ortalama çimlenme zamanı (OÇZ) ve \%50 çimlenme zamanı ( $\left.T_{50}\right)$ üzerine etkileri

\begin{tabular}{|l|c|c|c|c|c|c|}
\hline \multirow{2}{*}{$\begin{array}{l}\text { Salinity levels(dS m }{ }^{-1} \text { ) } \\
\text { (Tuz seviyesi) }\end{array}$} & \multicolumn{3}{|c|}{$\begin{array}{c}\text { MGT (Days) } \\
\text { OÇZ (Gün) }\end{array}$} & \multicolumn{3}{c|}{$\begin{array}{c}T_{50} \\
T_{50}\end{array}$} \\
\cline { 2 - 8 } & $\begin{array}{c}\text { UC } \\
\text { K }\end{array}$ & $\begin{array}{c}\text { C } \\
\text { NK }\end{array}$ & $\begin{array}{c}\text { Mean } \\
\text { Ort. }\end{array}$ & $\begin{array}{c}\text { UC } \\
\text { K }\end{array}$ & $\begin{array}{c}\text { C } \\
\text { NK }\end{array}$ & $\begin{array}{c}\text { Mean } \\
\text { Ort. }\end{array}$ \\
\hline 0,3 & 6.55 & 5.89 & $6.22 \mathrm{c}$ & 5.44 & 5.33 & $5.39 \mathrm{~d}$ \\
\hline 3.0 & 6.84 & 6.09 & $6.47 \mathrm{c}$ & 5.60 & 5.48 & $5.54 \mathrm{~d}$ \\
\hline 6.0 & 6.96 & 6.76 & $6.86 \mathrm{bc}$ & 6.34 & 5.77 & $6.08 \mathrm{c}$ \\
\hline 9.0 & 7,50 & 6.96 & $7,23 \mathrm{~b}$ & 6.71 & 6.36 & $6.53 \mathrm{~b}$ \\
\hline 12.0 & 7,73 & 8.00 & $7,86 a$ & 6.78 & 7,08 & $6.93 \mathrm{a}$ \\
\hline $\begin{array}{l}\text { Mean } \\
\text { Ort. }\end{array}$ & $7,12 \mathrm{a}$ & $6.74 \mathrm{a}$ & & $6.17 \mathrm{a}$ & $6.00 \mathrm{a}$ & \\
\hline
\end{tabular}

MGT: Mean Germination Time $T_{50}$ : The time of $50 \%$ germination OÇZ :Ortalama Çimlenme Zamanı $T_{50}$ : $\% 50$ Çimlenme Zamanı 
Süheri et al., 2019. Harran Tarım ve Gıda Bilimleri Dergisi, 23(1): 31-38

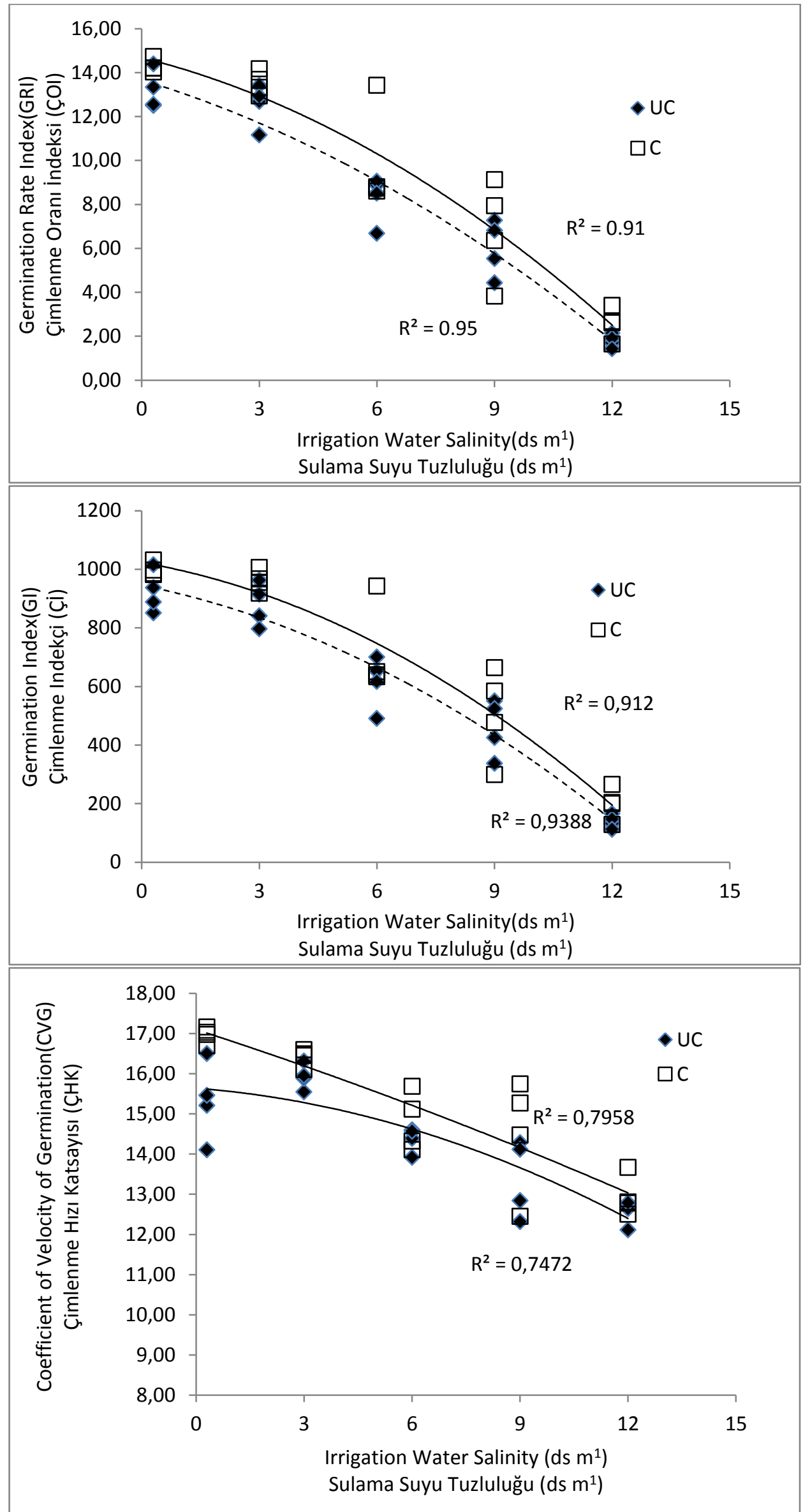

Figure 2. Variation of the germination rate index (GRI), germination index (GI) and coefficient of velocity of germination (CVG) of uncoated and coated alfalfa seed according to different irrigation water salinity. Lines describing the evolution of each parameter were obtained using polynomial regression.

Şekil 2. Farklı sulama suyu tuz seviyelerine göre kaplanmış ve kaplanmamış yonca tohumlarının çimlenme oranı indeksi (ÇOi), çimlenme indeksi (Çi) ve çimlenme hızı katsayıları (ÇHK) arasındaki varyasyonlar. 
The higher MGT and $T_{50}$ values were obtained with the increase in water salinity for both coated and uncoated seed. Earlier germinations were recorded for coated seeds as indicated by lower value of MGT and $T_{50}$ (Table 2). The coated seeds irrigated with tap water had lowest values of MGT (5.89) and $T_{50}$ (5.33) with no significant difference with uncoated seeds irrigated with tap water. The highest MGT (8.00) and $T_{50}$ (7.08) values was obtained from the coated seeds irrigated with the salt concentration of EC of $12.0 \mathrm{dSm}^{-1}$. MGT and $\mathrm{T}_{50}$ progressively delayed at salt concentration higher than EC of $3.0 \mathrm{dSm}^{-1}$ where the effect of salt concentration on MGT and $T_{50}$ is statistically significant.

\section{Conclusion}

The aim of this greenhouse pod experiment was to determine the differences between coated and uncoated seeds in terms of germination. Germination tests showed that the FGP, GRI, GI, CVG have decreased down and MGT, $T_{50}$ have increased up for both coated and uncoated seeds with increasing water salinity. There was found no difference between coated and uncoated seeds in terms of FGP, GI, CVG, MGT and $T_{50}$. The only difference between coated and uncoated seeds found in GRI values. The higher values have obtained from coated seeds relatively. GRI reflects the percentage of germination on each day of the germination period. It can be concluded that the coating increased the germinated seeds for each day. However, pod experiments may not give precise estimate of seedling emergence in the field. Field experiments should be conducted to understand the effects of seed coating on seedling and growth of alfalfa.

\section{References}

Al-Mudaris, M. (1998). Notes on various parameters recording the speed of seed germination. Der Tropenlandwirt-Journal of Agriculture in the Tropics and Subtropics, 99(2), 147-154.
Allen, S., Dobrenz, A., Schonhorst, M., \& Stoner, J. (1985). Heritability of $\mathrm{NaCl}$ tolerance in germinating alfalfa seeds 1. Agronomy Journal, 77(1), 99-101.

Assadian, N. W., \& Miyamoto, S. (1987). Salt Effects on Alfalfa Seedling Emergence 1. Agronomy Journal, 79(4), 710-714.

Benech Arnold, R., Fenner, M., \& Edwards, P. (1991). Changes in germinability, $A B A$ content and $A B A$ embryonic sensitivity in developing seeds of Sorghum bicolor (L.) Moench. induced by water stress during grain filling. New Phytologist, 118(2), 339-347.

Coolbear, P., FRANCIS, A., \& Grierson, D. (1984). The effect of low temperature pre-sowing treatment on the germination performance and membrane integrity of artificially aged tomato seeds. Journal of Experimental Botany, 35(11), 1609-1617.

Esechie, H. (1994). Interaction of salinity and temperature on the germination of sorghum. Journal of Agronomy and Crop Science, 172(3), 194-199.

Farooq, M., Basra, S., Afzal, I., \& Khaliq, A. (2006). Optimization of hydropriming techniques for rice seed invigoration. Seed science and technology, 34(2), 507-512.

Greenway, H., \& Munns, R. (1980). Mechanisms of salt tolerance in nonhalophytes. Annual review of plant physiology, 31(1), 149-190.

Gutterman, Y. (2012). Seed germination in desert plants: Springer Science and Business Media.

Hanson, C. H., \& Kehr, W. R. (1972). Alfalfa science and technology: American Society of Agronomy Madison, Wisconsin.

James, L. G. (1988). Principles of farm irrigation systems design: John Wiley and Sons Limited.

Johnson, D., Smith, S., \& Dobrenz, A. (1992). Genetic and phenotypic relationships in response to $\mathrm{NaCl}$ at different developmental stages in alfalfa. Theoretical and Applied Genetics, 83(6-7), 833-838.

Jones, K. W., \& Sanders, D. (1987). The influence of soaking pepper seed in water or potassium salt solutions on germination at three temperatures. Journal of Seed Technology, 97-102.

Kaufman, G. (1991). Seed coating: a tool for stand establishment; a stimulus to seed quality. HortTechnology, 1(1), 98-102.

Lehman, W., Robinson, F., \& Norman, M. (1979). Progress in developing salt tolerance in alfalfa. Paper presented at the Proc. 9th California Alfalfa Symp. Agronomy and Range Science Extension.

Li, R., Shi, F., Fukuda, K., \& Yang, Y. (2010). Effects of salt and alkali stresses on germination, growth, photosynthesis and ion accumulation in alfalfa (Medicago sativa L.). Soil Science and Plant Nutrition, 56(5), 725-733.

Maas, E. V., \& Hoffman, G. J. (1977). Crop salt tolerancecurrent assessment. Journal of the irrigation and drainage division, 103(2), 115-134.

Orchard, T. (1977). Estimating the parameters of plant seedling emergence. Seed science and technology.

Pedrini, S., Merritt, D. J., Stevens, J., \& Dixon, K. (2017). Seed coating: Science or marketing spin? Trends in plant science, 22(2), 106-116. 
TUiK. (2018). Türkiye İstatik Kurumu. Bitkisel Üretim İstatiksikleri. https://biruni.tuik.gov.tr/medas Erişim tarihi. 11 Mart 2018.

Ungar, I. A. (1967). Influence of salinity and temperature on seed germination.
Wang, W.-B., Kim, Y.-H., Lee, H.-S., Kim, K.-Y., Deng, X.-P., \& Kwak, S.-S. (2009). Analysis of antioxidant enzyme activity during germination of alfalfa under salt and drought stresses. Plant Physiology and Biochemistry, 47(7), 570-577. 